УДК 658.1

\author{
Бычкова Гульфира Мубараковна, \\ к.э.н., доцент, Ангарский государственный технический университет, \\ e-mail: gulfira_agta@mail.ru \\ ПРИЕМЫ, ИСПОЛЬЗУЕМЫЕ ПРИ РАЗРАБОТКЕ ВЫПУСКНОЙ \\ КВАЛИФИКАЦИОННОЙ РАБОТЫ
}

\title{
TECHNIQUES USED IN DEVELOPING THE WRC
}

Bychkova G.M.

\begin{abstract}
Аннотация. Разработан инструмент оценки соотношения полученных итогов с общей целью, конкретными задачами и темой ВКР.

Ключевые слова: инструмент, оценка, ВКР.

Abstract. The tool of an assessment of a ratio of the received results with the General purpose, specific tasks and a subject of WRC is developed.

Keywords: tool, assessment, WRC.
\end{abstract}

Проблема, на решение которой направлено данное исследование, это отсутствие инструмента оценки соотношения полученных итогов (результатов) с общей целью, конкретными задачами и темой ВКР (выпускной квалифрикационной работы) [1].

Актуальность темы исследования обосновывается недостаточностью проработки необходимых приемов для решения данной проблемы.

Цель исследования - разработка инструмента оценки соотношения полученных итогов с общей целью, конкретными задачами и темой ВКР.

Задачи исследования - систематизация соотношений заявленной темы с общей целью и конкретными задачами ВКР, причинно-следственных связей между результатами теоретической части (выводы по 1 главе) и выявлением резервов повышения эффрективности функционирования конкретного бизнеса (выводы по 2 главе), результатами исследования хозяйственных процессов (выводы по 2 главе) и рекомендациями по использованию выявленных резервов (выводы по 3 главе). Объект исследования - процесс формирования ВКР, предмет - приемы и методы, используемые в процессе фрормирования ВКР [2].

Для достижения поставленной цели разработана матрица соотнесения темы исследования, целей и задач, результатов (выводов) исследования в ВКР, пример использования которой представлен в таблице 1. Предлагаемый инструмент может быть рекомендован к использованию руководителям ВКР и обучающимся, а также заведующим выпускающих кафедр.

\section{ЛИТЕРАТУРА}

1. Невежин В.П. Как написать, офрормить и защитить выпускную квалификационную работу. - М.: ФОРУМ, 2012. С. 105.

2. Об образовании: федеральный закон РФ от 30.12.2008 г. № 307-Ф3 (с изм. и доп.) [Электронный ресурс]. [сайт]. [1997]. URL: http: www.consultant.ru (06.03.2019). 
Таблица 1

Матрица оценки согласованности содержания, целей, задач и выводов по выпускной квалификационной работе Тема ВКР: Особенности анализа торговых операций (на материалах ООО «Паритет»)

\begin{tabular}{|c|c|c|c|c|}
\hline Содержание работы & Цель и задачи исследования & Выводы по 1 главе & Выводы по 2 главе & Выводы по 3 главе \\
\hline $\begin{array}{l}\text { 1. Теоретические основы } \\
\text { анализа торговых опера- } \\
\text { ций. } \\
1.1 \text { Экономическая сущ- } \\
\text { ность торговых операций. } \\
1.2 \text { Классификация торго- } \\
\text { вых операций. } \\
1.3 \text { Особенности анализа } \\
\text { торговых операций. } \\
2 . \text { Анализ торговых опе- } \\
\text { раций ООО «Паритет». } \\
2.1 \text { Организационная ха- } \\
\text { рактеристика общества. } \\
2.2 \text { Внешний оринансовый } \\
\text { анализ хозяйственной } \\
\text { деятельности организа- } \\
\text { ции. } \\
2.3 \text { Оценка состояния } \\
\text { анализа торговых опера- } \\
\text { ций в организации. } \\
3 . \text { Рекомендации по со- } \\
\text { вершенствованию анали- } \\
\text { за торговых операций } \\
\text { ОоО «Паритет». } \\
3.1 \text { Совершенствование } \\
\text { подхода к анализу торго- } \\
\text { вых операций в обществе. } \\
3.2 \text { Обоснование эффрек- } \\
\text { тивности предлагаемых } \\
\text { мероприятий. }\end{array}$ & $\begin{array}{l}\text { Цель исследования: выяв- } \\
\text { ление резервов улучшения } \\
\text { аналитической системы } \\
\text { ООО «Паритет». } \\
\text { Задачи: } \\
\text { - исследовать экономиче- } \\
\text { скую сущность и фрункции } \\
\text { торговли; } \\
\text { - рассмотреть классифика- } \\
\text { ции торговых операций как } \\
\text { основы их анализа; } \\
\text { - исследовать и системати- } \\
\text { зировать особенности ана- } \\
\text { лиза торговых операций; } \\
\text { - выполнить организацион- } \\
\text { ную характеристику обще- } \\
\text { ства и оценить ее влияние } \\
\text { на постановку анализа; } \\
\text { - провести внешний ффинан- } \\
\text { совый анализ хозяйственной } \\
\text { деятельности; } \\
\text { - оценить состояние дел по } \\
\text { анализу торговых операций } \\
\text { и выявить резервы по со- } \\
\text { вершенствованию анализа; } \\
\text { - разработать рекомендации } \\
\text { по совершенствованию ана- } \\
\text { лиза торговых операций; } \\
\text { - обосновать эффективность } \\
\text { предлагаемых мероприятий } \\
\text { по совершенствованию ана- } \\
\text { лиза. }\end{array}$ & $\begin{array}{l}\text { Определена экономи- } \\
\text { ческая сущность тор- } \\
\text { говли, как экономиче- } \\
\text { ское посредничество } \\
\text { между производите- } \\
\text { лем и покупателем. } \\
\text { Систематизированы } \\
\text { функции торговли: } \\
\text { распределительная, } \\
\text { накопления, организа- } \\
\text { ции товародвижения и } \\
\text { др., которые являются } \\
\text { основой для анализа } \\
\text { торговли. } \\
\text { Рассмотрены методи- } \\
\text { ки анализа торговых } \\
\text { операций и выявлена } \\
\text { методика автора Са- } \\
\text { талкиной Н.И., которая } \\
\text { базируется на ком- } \\
\text { плексном и системном } \\
\text { подходе и в наиболь- } \\
\text { шей степени отвечает } \\
\text { задачам нашего ис- } \\
\text { следования. }\end{array}$ & $\begin{array}{l}\text { Выполнена организаци- } \\
\text { онная характеристика } \\
\text { общества, в целом соот- } \\
\text { ветствующая задачам } \\
\text { бизнеса, но не учтен фак- } \\
\text { тор сезонности продаж. } \\
\text { Проведен внешний фи- } \\
\text { нансовый анализ: отме- } \\
\text { чено отрицательное соот- } \\
\text { ношение динамики ос- } \\
\text { новных показателей: темп } \\
\text { роста себестоимости } \\
\text { (10,22\%) выше темпа ро- } \\
\text { ста оптового товарообо- } \\
\text { рота (6,75\%), и, как след- } \\
\text { ствие, снижение валовой } \\
\text { прибыли (6,2\%) и рента- } \\
\text { бельности продаж (2,2\%). } \\
\text { Выявлены резервы со- } \\
\text { вершенствования анали- } \\
\text { за торговых операций - не } \\
\text { охвачены анализом сле- } \\
\text { дующие направления: } \\
\text { динамика общего объема } \\
\text { товарооборота, анализ } \\
\text { товарного баланса, ана- } \\
\text { лиз оптового оборота в } \\
\text { ассортиментном разрезе. }\end{array}$ & $\begin{array}{l}\text { Рекомендуется дополнить } \\
\text { анализ следующими } \\
\text { направлениями: анализ ди- } \\
\text { намики общего объема то- } \\
\text { варооборота в действующих } \\
\text { и сопоставимых ценах; ана- } \\
\text { лиз товарооборота по квар- } \\
\text { талам; анализ товарного ба- } \\
\text { ланса; анализ оптового обо- } \\
\text { рота в ассортиментном раз- } \\
\text { резе. } \\
\text { С целью снижения влияния } \\
\text { фактора сезонности реко- } \\
\text { мендовано внести измене- } \\
\text { ние в систему мотивации } \\
\text { менеджеров по продажам - } \\
\text { премирование в виде про- } \\
\text { цента к окладу за привлече- } \\
\text { ние покупателей по сезон- } \\
\text { ным товарам. } \\
\text { Обоснована эфффективность } \\
\text { предлагаемых мероприятий } \\
\text { по использованию резервов } \\
\text { улучшения аналитической } \\
\text { системы: увеличение това- } \\
\text { рооборота в среднем на } \\
1,5 \% \text { сокращение запасов } \\
\text { на конец года на } 5 \% \text { увелели- } \\
\text { чение рентабельности про- } \\
\text { даж сезонного товара в } \\
\text { среднем на 0,3\%. }\end{array}$ \\
\hline
\end{tabular}

